\title{
An Investigation into using Nearpod as an Interactive Tool to Aid Students' Achievement and Motivation for Learning Educational Technology
}

\author{
Abdelrahman Mohamed Ahmed (Corresponding author) \\ College of Education, Sultan Qaboos University, PO box 32, Muscat, Oman \\ E-mail: abdoelhaj@squ.edu.om \\ Atiga Yousif Elmubark \\ College of Education, Sudan University of Science and Technology \\ PO box 407, Khartoum, Sudan \\ E-mail: atikaa5@hotmail.com
}

\begin{abstract}
Recently, the Department of Instructional and Learning Technology (ILT) at Sultan Qaboos University (SQU) has been using various interactive applications, such as Padlet, Nearpod, Wordwall, etc. The department has adopted and adapted its courses and teaching strategies to take better advantage of these advanced technologies in the teaching and assessment process. In this study, we selected Nearpod as an interactive tool for teaching an introductory course on Educational Technology (TECH3007). Nearpod is a web-based application that enhances students' motivation with interactive content and serves as an excellent tool for increasing students' achievement. The selection of this application is based on some of its features: it provides students with opportunities to interact and take effective control of their learning by offering immediate feedback and helping them draw on a map or diagram, respond to a poll question, post a note or image to a collaboration board or take a multiplechoice quiz. The purpose of this study was to explore the effectiveness of using the Nearpod web-based application as an interactive tool applied to students' achievement and motivation. A mixed-method (quantitative and qualitative) research method was used. The data collection tools applied in this research were achievement test, motivation questionnaire and interview. The sample in this study included 27 students enrolled in the course "Introduction to Educational Technology" at the College of Education, Sultan Qaboos University. The results of the study showed that there was a significant difference in the mean scores of the pre- and post-tests (before and after treatment) in favour of the post-test. The results also showed that the students participated in the study were very satisfied with the use of the interactive applications such as Nearpod in teaching and learning process.
\end{abstract}

Keywords: Nearpod, digital assessment tool, educational technology, motivation.

DOI: $10.7176 /$ RHSS/12-4-01

Publication date: February $28^{\text {th }} 2022$

\section{Introduction}

COVID-19 pandemic has influenced the teaching and learning process in higher education institutions and has effected the process of the interaction between instructors and learners. Therefore, higher education institutions started to search for emergency plan for e-learning, teaching strategies along with the requirement for modern technology applications. Fortunately, the present time is characterized by a plentiful use of advanced technologies in the educational context and its impact on teaching and learning at all levels of the education systems has been profound (Beránek, et al, 2016).

According to Cristol and Gimbert (2013), modern technologies have become a part of our everyday lives in recent years. Therefore, these modern technologies are affecting the instructional and learning processes more than ever before. Digital learning and technology environments are becoming an integral part of educational systems, and there is increasing evidence that smart technologies have the possibilities to increase the learning opportunities for the students' learning. Recently, many universities have introduced modern technologies as learning tools in the learning process (e.g., Wordwall, Padlet and Nearpod), and these learning platforms have been used by many instructors as learning tools in their courses (Beránek, et al, 2016). Consequently, to improve students' learning experiences and outcomes, educators have started developing learning environments that benefit from students' devices/technologies and the available onpen learning sources for better learning outcomes in education.

There is a growing researches showed that new learning technologies have benefit the traditional classroom environments and accordingly changed the learning strategies and affected students' learning needs to learning (Gedera, 2014; Bonk \& Graham, 2006; Keller, 2008). Bokhari, Ahmad, Alam and Masoodi (2011) suggest that the emergence of Learning Management Systems (LMS), Course Management Systems (CMS), virtual whiteboards (e.g., Jam Board, miro.com, Interactive Board) and mobile devices (e.g., iPads, etc.) have 
transformed the way we teach and learn. All these systems and applications are implemented to provide digital learning environments for campus-based students (Dilani, John \& Wright, 2013) and to provide better opportunities for classroom interaction and collaboration.

Turning to virtual learning due the Pandemic, the teachers at Sultan Qaboos University, College of Education, Department of Instructional and Learning Technology have noticed that the student; now online learners; participation, motivation and engagement were influenced negatively the thing which may affect those students' learning experiences and learning outcomes. Consequently, with the aim to improve the students' learning experiences and outcomes, the Department of Instructional and Learning Technology (ILT) has started using various digital applications such as Wordwall, Nearpod, Padlet, etc. Furthermore, the department has adopted and adapted its courses and teaching strategies to take better advantages of these advanced technologies in both teaching and assessment processes.

In this study, we have selected Nearpod as an online presentation platform and digital assessment tool for teaching the introductory course of Educational Technology (TECH3007) at Sultan Qaboos University, College of Education, Department of Instructional and Learning Technology. With the purpose of exploring the effectiveness of using Nearpod on students" achievement and motivation for learning educational technology.

\section{Objectives of the Study:}

The study aimed at achieving the following objectives:

1. Identifying the effect of Nearpod on student motivation towards online learning.

2. Compare the difference in the mean scores of students' achievement before and after the treatment.

3. Compare the difference in the mean scores of students' Motivation before and after the treatment.

\section{Problem of the Study}

Covid 19 pandemic took the World by surprise, and without previous warning, the World found itself obliged to physical distance. Therefore, educational institutions had to arrange to turn to distance education. However, distance is most effective way to fight Corona spread; there are negative effects that can occur due to the lack of direct communication between the teacher and students and between students each other, such as decreased interaction and motivation to learn and a feeling of isolation, which can affect students' achievement. Turning to online education teachers at Sultan Qaboos University noticed that most of their students had become demotivated to learn and less engaged with the new mode of teaching strategies. The researcher had observed that the students in the course "educational technology concepts" did not participate, they yawned, stared blankly, and they lost track of the conversation from zoning out. It is obvious that some students had become apathetic and bored. Therefore, they were not living up to their full potential to learn new concepts.

In an attempt to reduce the negative effects that occurred Nearpod was used to investigate its impact on students' motivation and achievement for learning Educational Technology concepts in educational technology (TECH3007) at the College of Education, Sultan Qaboos University. More specifically, the research intended to answer the following research questions:

1. What is the effect of Nearpod application on students' motivation towards learning?

2. Is there any significant difference in the mean scores of students' achievement before and after the treatment?

3. Is there any significant difference in the mean scores of students' Motivation before and after the treatment?

\section{Literature review}

Good students' learning achievement is the output of number of elements such as interactive learning, motivation, engagement and participation. This literature survey will briefly demonstrate how Nearpod application can help in fostering these elements. The purpose of this research was to investigate if integrating an interactive learning technology tool as Nearpod into the teaching/learning process had an effect on students' motivation and achievement.

According to Sanmugam, Selvarajoo, Ramayah and Lee (2019), Nearpod is a web-based learning application that facilitates and controls interactivities during the learning experience settings (Figure 1). It can be used as a teaching tool to deliver lessons with interactive media as well as assessments; it provides formative assessment to get real-time insights into student learning, and summative assessment for final assignments or exams. Webb (2020) also defined Nearpod as an online presentation and engagement platform that allows professors and students to engage with one another, record completion and track overall participation. There are a variety of tools included in the one-stop platform, and because it's web-based, it can be accessed from anywhere. Nearpod integrates with Google Slides for those who already have their slides created in that format. 


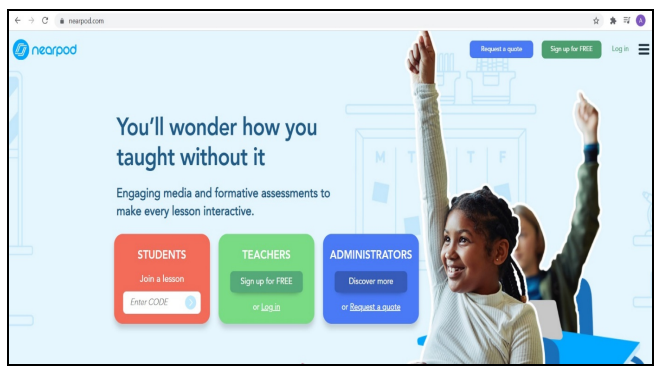

Figure 1: A typical Nearpod layout

One of the main advantages of integrating Nearpod into teaching process is to support active learning in the classroom, becuase it offers different types of ways to engage students in the classromms (Mattar, 2018). It offers nine types of formative assessments to capture student understanding in any lesson (Figure 2). It provides students opportunities to interact and give them effective control of their learning including immediate feedback, help them draw on a map or diagram, respond to a poll question, post a note or image to a collaboration board, or take a multiple-choice quiz. For more details, please visit the Nearpod website: https://nearpod.com/nearpodsite-license.

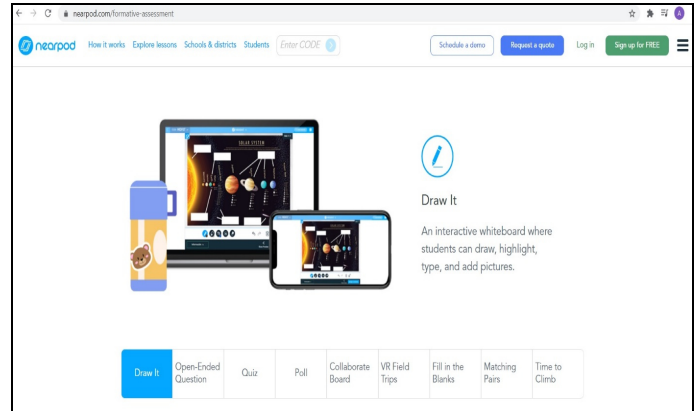

Figure 2: The nine types of formative assessments offered by Nearpod.

Nearpod also allows for easier grouping of students so that peer feedback can be provided (López \& Mazario, 2016). Nearpod is a great tool for formative assessment not only due to its ability to collect a vast amount of data quickly, but also for its ease of use and variety of implementations. When using any formative assessment tool, the questions cannot be solely factual and static, there needs to be a variety of question types and questions that allow for higher level thinking (DeBoer et al., 2014). Students can answer open-ended questions, take polls, draw pictures, experiment with 3D images, and use simulation software within Nearpod. Any data from student use is instantly saved and can easily be retrieved by the teacher during the lesson or at another time. In this study the researcher used this application with students to present the lectures, poll questions, collaborative whiteboard and experiment with 3D images, and engage students as groups in collaborative activities (See Figure 3).

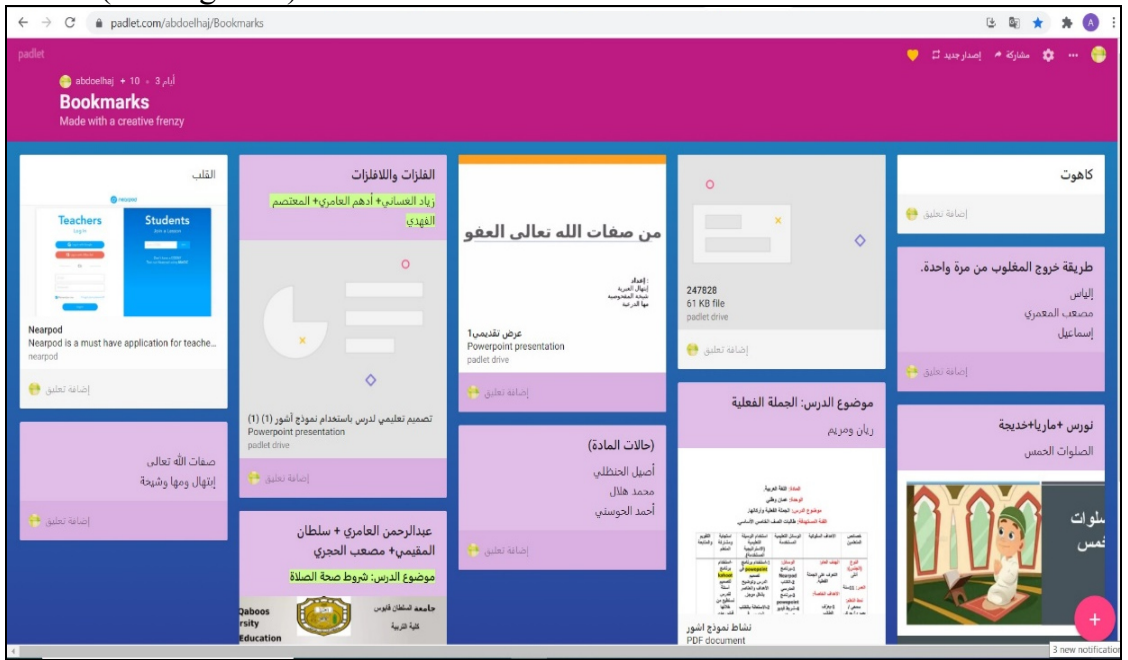

Figure 3: Sample of a collaborative activity in small groups using Nearpod.

Active learning requires students to complete meaningful activities and think about what they are doing and learning. It is often contrasted to a traditional in-person or recorded online lecture where students passively receive information from the professor. Nearpod augments the traditional lecture by adding engaging activities 
throughout the lecture (Corral, 2015). According to Corral (2015) active learning could looks like the following: 1) pausing lecture \& students make notes, 2) pausing lecture and students discuss what was presented, 3) pausing lecture to poll students; students discuss answers; faculty-led tutorial on correct answer, 4) cases or worked problems, 5) flipped classroom (lecture), and 6) team-based learning (small groups).

According to Kusurkar, Ten Cate, Vos, Westers and Croiset (2013) motivation is an essential element in the academic performance. It can be defined as a form of cognitive and emotional arousal that influence a learner's academic achievement (Vallerand et al., 1992). It keeps students' attention and behavior as well as provides more energy needed to lead tasks to completion. Therefore, high levels of motivation are associated with good academic performance (Kusurkar et al., 2013). Wigfield, Tonks and Klauda (2009) state that there are two types of motivations, extrinsic and intrinsic, which lie as groundwork underpropping a large number of theories of motivation such as self-determination theory (Deci, Vallerand, Pelletier, \& Ryan, 1991) and self-efficacy theory (Zimmerman, 2000). These theories provide great understanding of academic motivation in teaching and learning setting, and valuable information regarding how students adjust to various learning environments (Li \& Zheng, 2017). For example, the student is an active processor and interpreter of the classroom setting, so student's academic motivation can be enhanced by engaging students in meaningful learning activities (e.g., using Nearpod, Padlet, Wordwall, ...) (Gredler, 2001). Motivation can have a variety of effects on students' behavior, preferences, and results. For instance, motivation can:

- help students to direct their attention toward tasks that need to be done,

- allow students to do the tasks in shorter periods of time as well as maintain attention during a longer time,

- minimize distractions and resist them better,

- affect how much information we retain and store,

- Influence the perception of how easy or difficult tasks can appear, and

- Most importantly, motivation urges to students perform an action.

Improving learning outcomes using interactive learning tools to facilitate more interactive learning environment has been an active area of research for more than a decade. Several studies focusing on the effectiveness of technology learning tools suggest that these interactive learning tools (such as Nearpod, Wordwall) have the opportunity to improve students' learning achievements, motivation and engagement (e.g., Hakami, 2020; Potter, 2017; Rebecca, 2016; McKay \& Ravenna, 2016, Beránek, et al., 2016). Hakami (2020), conducted a study to explore the Use of Nearpod as a Tool to Promote Active Learning in Higher Education in a BYOD Learning Environment at Sharoura College of Science and Arts, Najran University. The research used quantitative method. The data was collected by using an electronic learning questionnaire applied to (74) female students. The findings of the study showed that the Nearpod and BYOD model have promoted active learning in the classroom. Students were very satisfied with integrated learning environment, and they commended Nearpod in all courses specially those ones taught by video-conference learning system. Potter (2017), also conducted a study to explore how integrating digital formative assessment impacts the learning of Sixth-Grade science students. The results showed that the students preferred Chromebooks over paper and pencil. However, students recognized that they learn and are motivated by both types of formative assessment like Nearpod application.

Inaddition, Rebecca (2016) at Russellville High School investigated the impact of using Nearpod as a tool of active learning in the high school science classroom. It tested the difference between active learning with Nearpod and inactive learning with PowerPoint. The research used experimental method and both qualitative and quantitative data was used. The results indicated that Nearpod does not have a great effect on student grades when compared to active learning with the presentation program PowerPoint. Thus, active learning seems to be a common factor of how much students learn, not a computer program with opportunities for active participation. However, students and teachers both prefer the active learning opportunities provided by Nearpod as Nearpod gave greater student confidence in material than when using PowerPoint. McKay \& Ravenna (2016) also conducted study to investigate the influence of using Nearpod and its impact on progress monitoring to determine students' academic performance, measure their degree of improvement, and assess the efficacy of instruction. The research used quasi-experimental method. The results of the study indicated that the use of the Nearpod improved student engagement and whole group assessment in a single lesson.

Moreover, Beránek, et al., (2016) conducted study to evaluate the impact of an interactive classroom application on student learning outcomes. The research used experimental method. The results found that the use of Nearpod platform has resulted in significantly improved learning outcomes in the programming course. The results also indicated that the effectiveness of using an interactive learning platform varies depending on the type of the course and depends on attendance pattern. Additionally, a small fraction of the survey respondents felt that they would have learned more without the Nearpod application. Lowry-Brock (2016) investigated the impact of the interactive presentation tool Nearpod on the success of high school science students. Student achievement was measured using Pretests and Posttests, daily quizzes, classroom, and laboratory activities. Student and teacher attitude was measured using surveys and journals. The results indicated that Nearpod does not have a 
great effect on student grades when compared to active learning with the presentation program PowerPoint. However, students and teachers both prefer the active learning opportunities provided by Nearpod. İnaddition, an action research project conducted by Banitt, Theis and Leeuwe (2013) to determine the effects of technology integration on student engagement in the secondary classroom. Their results showed an average overall increase of $5-10 \%$ in student engagement as well as improved student enjoyment and enthusiasm for lessons involving technology when compared to traditional, parallel lessons. The results also indicated that incorporating technology elements into lessons might be an effective way to increase student engagement and motivation.

\section{Method}

The research used a mixed method (quantitative and qualitative). The research data were gathered using three instruments: an assessment test, an interview and a questionnaire.

\subsection{Research design}

Based on the results of the most recent studies, its clear that technology applications have positive effect on promoting active learning in the classroom and a high impact on students' learning outcomes (Hakami, 2020; Auerbach, Higgins, Brickman, \& Andrews, 2018; Cavanagh et al., 2018; Prince, 2004), in this study, the researcher developed a learning environment which allow the students to be active during the class sessions and to increase their motivation for learning educational technology. Therefore, the research used a web based application (Nearpod) as open source to support and manage learning contents on Moodle. The Google Meet was also used for the synchronous sessions during the class. The contents on the Nearpod contained various types of sources such as PowerPoint presentations, Mind maps, real time assessment and group's activities. Consequently, this research adapted a quasi-experimental design with pre and posttest and a pre-post questionnaire on motivation towards learning. Bryman (2012) stated that, by answering "what" questions and explore opinions, research results can be enriched when using quantitative methods to address the research questions; so, a quantitative approach was also used in this study to explore students' participations and engagement by measuring their involvement and participations in the class discussion boards, electronic boards, discussion forums and the real online assessment on Nearpod. Consequently, the data collected from the LMS activity log records and the real time activities on the Nearpod will be used.

\section{Population and sample of the study}

The population of this research consisted of students at the College of Education who intended to take the Introduction to Educational Technology course (TECH3007) in their fourth academic semester. The sample for this study consisted of students who were registered in an online "Introduction of Educational Technology" course (TEC3007) at the Department of Instructional and Learning Technologies during Summer 2021. The total number of students was 20 . The majority of the participants in this study were male $(60 \%)$, while the rest were female $(40 \%)$.

\subsection{Research Instruments}

Based on the nature of this research, the researchers were used three instruments for data collection. These are: a motivation survey, an achievement test and activity reports.

\subsubsection{Achievement test (pre and posttest)}

The researcher designed pre and posttest to measure the students' achievements before and after treatment using Nearpod. The achievement test consisted initially of 35 questions (20). The test was sent to four referees for the validation, and it was modified according to their comments. The reliability coefficient was calculated and was found to be 0.91 .

\subsubsection{Motivation questionnaire (ARCS)}

This research used the Instructional Materials Motivation Survey (IMMS) conducted by Keller which was aimed to measure the students' motivation towards learning. The items of this survey can be found in Vallerand et al. (1992) [30]. Pre-post questionnaires were used to collect data regarding the students' views on the effect of learning process in terms of activities and practices while using Nearpod application with the learning process using Google Meet and the Moodle. The survey was divided into two sections: section one had demographic information, while section two focused on the students' views towards learning when integrated with the Nearpod. Section two consisted of 36 items: 12 items represented attention, nine each for relevance and confidence and six for satisfaction. The IMMS was administered at the beginning of the course for the students and after the treatment (after four weeks). The survey was piloted and reviewed by four instructors from the college of education. The researcher considered all the reviewers' comments for approving the final version. The survey reliability estimate was considered (0.89).

\subsubsection{Interviews}

The interviews were conducted with the students after they completed four weeks of treatment using Nearpod as an interactive learning tool. The main goal of the interviews was to allow them to talk about the benefits that 
they gained from the application and help them study the content of the course.

\subsection{Procedures}

The study was conducted at the Instructional and Teaching Technology department, College of Education, Sultan Qaboos University. All students who enrolled to "Introduction to Educational Technology" course took part in the study at the summer semester for the academic year 2020/2021. All students studied the course through Moodle e-learning platform supported with learning activities using Nearpod (synchronous engagement). Nearpod was used as a tool to enhance teaching and learning process. It used to provide rapid feedback and to evaluate the students' understanding of the course material that is being presented during the 4 weeks in the lecture and the lab sessions. At the beginning of the semester, the achievement pretest and the pre questionnaire of the motivation were given to students. By the end of the treatment, the achievement posttest was given to students and the post perception and motivation questionnaires links were sent to them. The duration of the experiment in this study was 4 weeks with 8 -hour class period per week.

\section{Results}

6.1 What is the effect of a digital assessment tool (Nearpod) on student motivation towards learning?

To answer the first research question related to students' motivation, a questionnaire was used after treatment to measure the students' motivation towards learning. Descriptive statistics for the four dimensions and for each of the 36 items assessed using a five-point Likert scale of the students' motivation towards learning are presented in Table 1.

Table 1. Mean scores of students' motivation towards learning using Nearpod

\begin{tabular}{|c|c|c|c|}
\hline Statement \# & $\mathbf{N}$ & Mean & SD \\
\hline The beginning of the course was interesting; it got my attention. & 20 & 3.50 & 1.000 \\
\hline These materials are eye-catching & 20 & 3.90 & 0.6407 \\
\hline The quality of the writing helped to hold my attention. & 20 & 2.65 & 0.6708 \\
\hline This course is so abstract that it was hard to keep my attention. & 20 & 3.40 & 0.8826 \\
\hline The pages of this course look dry and unappealing. & 20 & 4.00 & 0.3244 \\
\hline The way the information is arranged on the pages helped keep my attention. & 20 & 3.65 & 0.8127 \\
\hline This course has things that stimulated my curiosity. & 20 & 2.9 & 1.1653 \\
\hline The amount of repetition in this course caused me to get bored sometimes. & 20 & 3.95 & 0.5104 \\
\hline I learned some things that were surprising or unexpected. & 20 & 4.05 & 0.8256 \\
\hline $\begin{array}{l}\text { The variety of reading passages, exercises, illustrations, etc., helped keep my attention } \\
\text { on the course. }\end{array}$ & 20 & 4.45 & 0.5104 \\
\hline The style of writing is boring. & 20 & 3.35 & 0.7452 \\
\hline There are so many words on each page that it is irritating. & 20 & 2.85 & 0.7452 \\
\hline Total (Attention) & & 3.55 & 0.7361 \\
\hline It is clear to me how the content of this material is related to things I already know. & 20 & 3.90 & 0.4472 \\
\hline $\begin{array}{l}\text { There were stories, pictures, or examples that showed me how this material could be } \\
\text { important to some people. }\end{array}$ & 20 & 3.95 & 0.6863 \\
\hline Completing this course successfully was important to me. & 20 & 2.30 & 1.0809 \\
\hline The content of this material is relevant to my interests & 20 & 3.50 & 0.6882 \\
\hline There are explanations or examples of how people use the knowledge in this course. & 20 & 3.70 & 0.7327 \\
\hline $\begin{array}{l}\text { The content and style of writing in this course convey the impression that its content is } \\
\text { worth knowing. }\end{array}$ & 20 & 3.90 & 0.5525 \\
\hline This course was not relevant to my needs because I already knew most of it. & 20 & 2.55 & 0.6863 \\
\hline $\begin{array}{l}\text { I could relate the content of this course to things I have seen, done, or thought about in } \\
\text { my own life. }\end{array}$ & 20 & 4.00 & 0.5620 \\
\hline The content of this course will be useful to me. & 20 & 4.00 & 0.5620 \\
\hline Total (Relevance) & & 3.53 & 0.6665 \\
\hline When I first looked at this course, I had the impression that it would be easy for me. & 20 & 3.18 & 0.7445 \\
\hline This material was more difficult to understand than I would like for it to be. & 20 & 3.55 & 0.6863 \\
\hline $\begin{array}{l}\text { After reading the introductory information, I felt confident that I knew what I was } \\
\text { supposed to learn from this course. }\end{array}$ & 20 & 4.20 & 0.6948 \\
\hline $\begin{array}{l}\text { Many of the pages had so much information that it was hard to pick out and remember } \\
\text { the important points. }\end{array}$ & 20 & 3.65 & 0.4894 \\
\hline As I worked on this course, I was confident that I could learn the content. & 20 & 3.00 & 0.5225 \\
\hline The exercises in this course were too difficult. & 20 & 3.65 & 0.4894 \\
\hline
\end{tabular}




\begin{tabular}{|c|c|c|c|}
\hline Statement \# & $\mathbf{N}$ & Mean & SD \\
\hline $\begin{array}{l}\text { After working on this course for a while, I was confident that I would be able to pass a } \\
\text { test on it. }\end{array}$ & 20 & 3.45 & 0.6048 \\
\hline I could not really understand quite a bit of the material in this course. & 20 & 2.95 & 0.7256 \\
\hline $\begin{array}{l}\text { The good organization of the content helped me be confident that I would learn this } \\
\text { material. }\end{array}$ & 20 & 3.95 & 0.394 \\
\hline Total (Confidence) & & 3.51 & 0.5946 \\
\hline $\begin{array}{l}\text { Completing the exercises in this course gave me a feeling of satisfaction and } \\
\text { accomplishment. }\end{array}$ & 20 & 3.10 & 1.0208 \\
\hline I enjoyed this course so much that I would like to know more about this topic. & 20 & 4.30 & 0.6569 \\
\hline I really enjoyed studying this course. & 20 & 4.15 & 0.3663 \\
\hline $\begin{array}{l}\text { The wording of feedback after the exercises, or of other comments in this course, } \\
\text { helped me feel rewarded for my effort. }\end{array}$ & 20 & 2.55 & 0.9445 \\
\hline I felt good to successfully complete this course. & 20 & 3.65 & 0.7452 \\
\hline It was a pleasure to work on such a well-designed course & 20 & 4.05 & 0.6048 \\
\hline Total (Satisfaction) & & 3.55 & 0.6811 \\
\hline & & 3.54 & $\mathbf{0 . 6 8 5 2}$ \\
\hline
\end{tabular}

As indicated in Table 1, the mean scores for the individual dimensions (attention, relevance, confidence and satisfaction) ranged from 3.51 to 3.63 , with an overall mean score of 3.55 , which indicated that the students had high motivation towards learning using Nearpod as a digital assessment and interactive learning tool (mean = 3.54). This result could be attributed to the fact that Nearpod has many functions and provides a learning environment that supports more effective instruction and offers countless ways to incorporate active learning activities into instruction (e.g., drawing on a board, poll question, posting a note, ...). This result is supported by (McClean and Crowe, 2017) study, who indicate that Nearpod can be used to help teachers to create an active learning environment that present different learning tasks for more students' involvement even in a large class.

More specifically, as shown in Table 1, there were 24 out of 36 statements had high mean scores ranging between 3.40-4.45. The top six statements of high motivation among the students towards learning using Nearpod after the treatment were as follows: (10) The variety of reading passages, exercises, illustrations, etc., helped keep my attention on the course $(\mathrm{M}=4.45)$; (32) I enjoyed this course so much that I would like to know more about this topic $(\mathrm{M}=4.30)$; (24) after reading the introductory information, I felt confident that I knew what I was supposed to learn from this course $(\mathrm{M}=4.20)$; (33) I really enjoyed studying this course (4.15); (9) I learned some things that were surprising or unexpected (4.55); and (36) it was a pleasure to work on such a welldesigned course (4.05). This means that the Nearpod application has positive influences on student learning, including the ability to enhance their learning experiences and increase their satisfaction with their learning, because it gives them more opportunities to be involved in learning activities and dynamic interaction between them (Jing \& Yue, 2016). These findings are in congruence with several studies (e.g., Banitt et, al, 2013; LowryBrock, 2016; Hakami, 2020). These studies in general indicate that incorporating technological elements into lessons using Nearpod might be an effective way to increase student motivation and engagement. They reported that students and teachers both preferred the active learning opportunities provided by Nearpod.

The interviews with the students supported the above result. They suggested that most of the students in the class agreed that Nearpod made them enjoy studying the course, helped them pay more attention, helped them better learn and understand the material, made them more involved, increased group participation and helped them understand the material that they knew. The results indicated that Nearpod, as an interactive learning tool, is a very useful learning tool for both students and lecturers - in particular, its attention-generating features.

Table 2. Students' motivation towards learning using Nearpod (one-sample test)

\begin{tabular}{|c|c|c|c|c|c|c|}
\hline \multirow{2}{*}{ Students' motivation score } & N & df & Mean & SD & t & Sig. (2-tailed) \\
\cline { 2 - 8 } & 20 & 19 & 4.17 & .335 & 60.33 & .001 \\
\hline
\end{tabular}

Moreover, as illustrated in Table 2, students were engaged and involved in active learning when using Nearpod because it provides and presents different learning tasks and learning materials. It seemed they gained high motivation towards learning using Nearpod $(\mathrm{t}=62.33, .001, \mathrm{p}<0.05)$. These findings are in congruence with several studies (e.g., Lowry-Brock, 2016; Beránek et al., 2016; McClean and Crowe 2017; Sanmugam, Selvarajoo, Ramayah \& Lee, 2019; Hakami, 2020). In general, these studies indicate that Nearpod can be used to support instructors to involve students in active learning by presenting different learning tasks and learning materials, even in a large class. It can be concluded that Nearpod provides an enjoyable learning environment for students that might influence their motivation towards learning, because it has been found to be very useful by both students and lecturers, particularly for its attention-generating features (Beranek, Bory \& Vacek, 2014). 


\subsection{Are there any significant differences in the mean scores of students' motivation before and after treatment?}

To answer this research question, a paired samples test was used to compare the mean scores of students' motivation before and after treatment. Nineteen students registered in the course completed the pre-motivation scale, while all the students participating in the study $(\mathrm{N}=20)$ completed the post-motivation scale. Table 3 below shows the mean differences in students' motivation before and after the treatment.

Table 3. Pared-sample T- Test scores for differences in the mean scores of students' motivation

\begin{tabular}{|c|c|c|c|c|c|c|}
\hline Motivation & $\mathrm{N}$ & Mean & SD & Df & t & Sig.(2-tailed) \\
\hline Pre & 19 & 3.78 & .7518 & 19 & 3.456 & .001 \\
\hline Post & 20 & 3.83 & .6544 & & & \\
\hline
\end{tabular}

Table 3 shows that there is a significant difference in the mean scores of students' motivation before and after the treatment $(\mathrm{t}=0.248,0.807, \mathrm{p}<0.05)$ in favour of the post-questionnaire after the treatment. This result could be attributed to the role of Nearpod's digital assessment and interactive learning tools in encouraging student engagement as well as improving student enjoyment and enthusiasm for active tasks involving technology (such as quizzes, polls, the drawing function, collaborations and open-ended questions) when compared to traditional, parallel tasks. The active tasks offered by the learning tools (Nearpod) during the lecture time may provide more opportunities for the students to collaborate and react as active agents in the learning setting settings (Daniela, et al, 2018). This finding is supported by Hakami (2020)'s finding, which reported that Nearpod and the BYOD model have promoted active learning in the classroom, and students were very satisfied with the integrated learning environment using Nearpod.

\subsection{Are there any significant differences in the mean scores of students' achievement before and after the treatment?}

To answer this research question, an independent sample t-test was used to test the mean differences in students' achievement before and after the treatment. Table 4 below shows the mean differences in students' scores in the pre- and post-tests.

Table 4. Pared-sample T- Test scores for differences in the mean scores of the pre- and post-test

\begin{tabular}{|c|c|c|c|c|c|c|}
\hline Test & $\mathrm{N}$ & $\mathrm{df}$ & Mean & $\mathrm{SD}$ & $\mathrm{t}$ & $\begin{array}{c}\text { Sig. } \\
(2 \text {-tailed) }\end{array}$ \\
\hline Pre test & 20 & 19 & 8.85 & 2.676 & 5.106 & .001 \\
\hline Post test & 20 & & 11.58 & 1.184 & & \\
\hline
\end{tabular}

Table 4 indicates that there is a significant difference in the mean scores on the test before and after treatment $(\mathrm{t}=5.106,0.001, \mathrm{p}<0.05)$ in favour of the post-test. This result could be attributed to the interactive technology and online assessment activities embedded in Nearpod (such as quizzes, polls, drawing functions, collaboration and open-ended questions), which allow for the inclusion of a variety of media, making learning comprehensible and engaging for students. Consequently, this will create meaningful learning environments that help to check for students' understanding (Sanmugam, Selvarajoo, Ramayah \& Lee, 2019). This interactive learning environment results in students taking ownership in participating in learning activities and subsequently developing their knowledge and has a significant impact on students' performance in the post-test.

In addition, the collaborative nature of the Nearpod application provided opportunities for students to interact with the content, activities, lecturer and their peers. This finding is supported by (Sanmugam, Selvarajoo, Ramayah \& Lee, 2019), who found that using Nearpod seems to offer an alternative teaching approach compared to traditional lectures to engage students for a better and enhanced learning experience. This result is also in alignment with that of McKay and Ravenna (2016). They reported that the use of the Nearpod app improved student engagement and whole-group assessment in a single lesson.

This finding also supports the findings of Beránek et al's (2016), which showed that both full-time and parttime students benefitted from the introduction of interactive learning using the Nearpod platform, with full-time students significantly reducing their failure rate and part-time students reaching higher grades. However, this finding contradicts the findings of Lowry-Brock (2016), which showed that Nearpod does not have a major effect on student grades when compared to active learning with the presentation program PowerPoint. However, students and teachers both prefer the active learning opportunities provided by Nearpod.

\section{Conclusion}

The purpose of this study was to explore the effectiveness of using Nearpod web based application as an interactive tool on students' achievement and motivation. The findings of this study are in congruence with a large body of relevant literature. The results of the study showed that there is a significant difference in the mean scores of the pre and posttest in favor of the posttest. Furthermore, with regard to the students motivation, the study showed that, students participated in the study were very satisfied with the integration of Nearpod in the classes as it promoted more interaction, collaboration among them and enhanced communication with the 
teacher. Thus, it can be said that this application creates motivation in the learners and results in better performances. However, in forthcoming research we might need to further explore the effectiveness of the various tools and attributes of Nearpod as interactive tool by comparing the results of students who studied with the Nearpod application with other groups who did not.

\section{References}

Auerbach, A., Higgins, M. Brickman, M. \& Andrews, T (2018). Teacher knowledge for active-learning instruction: what do instructors need to know to be effective. CBE - Life Sciences Education, vol. 17, no. 1, pp.1-14,

Beranek, M., Bory, P. \& Vacek, V. (2014). Platform for Supporting Student Learning at Unicorn College. Higher Education, 67(6), pp. 711-719.

Beránek, M., Feuerlicht, G., Kováŕ, V., Petkovová, L. \& Vacek, V. (2016). Evaluating the Impact of an Interactive Classroom Application on Student Learning Outcomes. Int'l Conf. e-Learning, e-Bus., EIS, and e-Gov. | EEE'16 |

Bokhari, M.U., Ahmad, S. and Alam, S. (2011). Modern Tools and Technologies for Interactive Learning. In Proceedings of the Computing For Nation Development, Bharati Vidyapeeth's Institute of Computer Applications and Management, New Delhi, , pp. 1-4, Mar 2011.

Bonk, C., \& Graham, C. (2006). Handbook of blended learning environments. Pfeiffer.

Bryman, A. (2012). Social research methods. New York: Oxford University Press.

Cavanagh, A., Chen, X., Bathgate, M., Frederick, J., Hanauer, D. \& Graham, M. (2018). Trust, Growth Mindset, and Student Commitment to Active Learning in a College Science Course. CBE-Life Sciences Education, vol. 17, no. 1, pp. 1-8. https://doi.org/10.1187/cbe.17-06-0107

Corral, J. (2015). Active Learning: 3 ways for higher education lectures. Retrieved from https://www.slideshare.net/JanetTworek/active-learning-3-easy-ways-for-higher-education-lectures

Cristol, D., \& Gimbert, B. (2013). Academic Achievement in BYOD Classrooms. QScience Proceedings, 2013(3), 15. https://doi.org/10.5339/qproc.2013.mlearn.15

Daniela, L., Visvizi, A., Gutiérrez-Braojos, C., \& Lytras, M. D. (2018). Sustainable higher education and Technology-Enhanced Learning (TEL). Sustainability (Switzerland), 10(11). https://doi.org/10.3390/su10113883

Deci, E., Vallerand, R., Pelletier, L. \& Ryan, R. (1991). Motivation and education: The self-determination perspective. Educ. Psychol, 26(3), 325-346. https://doi.org/10.1207/s15326985ep2603\&4_6

Dilani, P. John, J. \& Wright, N. (2013). An analysis of Moodle in facilitating asynchronous activities in a fully online university course. International Journal of Science and Applied Information Technology (IJSAIT), vol. 2, no, 2, pp. 6-10.

Gedera, P. (2014). Students' experiences of learning in a virtual classroom. International Journal of Education and Development Using Information and Communication Technology (IJEDICT), 10(4), 93-101.

Hakami, M. (2020). Using Nearpod as a Tool to Promote Active Learning in Higher Education in a BYOD Learning Environment. Journal of Education and Learning, 9(1), 119-126

Jing, T. \& Yue, S. (2016). Real-Time Assessment with Nearpod in the BYOD Classroom. In Assessment for Learning Within and Beyond the Classroom (pp. 103-107). https://doi.org/10.1007/978-981-10-0908-2 10

Keller, J. M. (2008). "An integrative theory of motivation, volition, and performance." Technology, Instruction, Cognition, and Learning 6(2): 79-104.

Kusurkar, R., Ten Cate, J., Vos, P., Westers, P. \& Croiset, G. (2013). How motivation affects academic performance: a structural equation modelling analysis. Advances in health sciences education, 18, 57-69.

Li, S. \& Zheng, J (2017). The effect of academic motivation on students' English learning achievement in the eSchoolbag-based learning environment. Smart Learning Environments, 4(3), 1-14. https://doi.org/10.1186/s40561-017-0042-x

Lowry-Brock, M. (2016). The effect of using nearpod as a tool of active learning in the high school science classroom. A master thesis desertation, unpublished, Montana State Unıversity, Montana.

Mattar, J. (2018). Constructivism and connectivism in education technology: Active, situated, authentic, experiential, and anchored learning. RIED. Revista Iberoamericana de Educación a Distancia, 21(2), 201. https://doi.org/10.5944/ried.21.2.20055

McClean, S., \& Crowe, W. (2017). Making room for interactivity: Using the cloud-based audience response system Nearpod to enhance engagement in lectures. FEMS Microbiology Letters, 364(6). https://doi.org/10.1093/femsle/fnx052

McKay, L., \& Georgianna Ravenna, G. (2016). Nearpod and the Impact on Progress Monitoring. International Conference on Mobile Technology in Teacher Education, 27(1), P. 23-27.

Potter, E. (2017). "How Integrating Digital Formative Assessment Impacts The Learning Of Sixth-Grade Science Students". School of Education Student Capstone Theses and Dissertations. 4316. 
https://digitalcommons.hamline.edu/hse all/4316

Sanmugam, M., Selvarajoo, A., Ramayah, B., \& Lee, K. W. (2019). Use of Nearpod As Interactive Learning Method (vol. 1, pp. 8908-8915). INTED2019 Proceedings. https://doi.org/10.21125/inted.2019.2219

Talysheva, I., Pegova, K. \& Khaliullina, L. (2021). The Use of Electronic Educational Resources of the University as a Means of Increasing the Educational Motivation of Students. International Journal of Emerging Technologies in Learning, vol. 16, no. 01, pp. 289-304. https://doi.org/10.3991/ijet.v16i01.16799

Vallerand, J., Pelletier, G., Blais, R., Briere, M., Senecal, C., \& Vallieres, F. (1992). The Academic Motivation Scale: A Measure of Intrinsic, Extrinsic, and Amotivation in Education. Educational and Psychological Measurement, 52(4), 1003-1017. https://doi.org/10.1177/0013164492052004025

Webb, Sh. (2020). Increasing Engagement with Nearpod in Shaun, F. et al., (2020). Technology Tools For Teachıng In Higher Educatıon, The Practical Handbook Series. Accessed on 23 August, 2021. Avialable at: https://ecampusontario.pressbooks.pub/techtoolsforteaching/chapter/05-increasing-engagement-withnearpod/

Wigfield, A. Tonks, S. \& lauda, S. (2009). Expectancy-value theory, in Handbook of Motivation at School. Expectancy-value theory, pp. 55-75.

Zimmerman, B. (2000). Self-efficacy: An essential motive to learn. Contemp. Educ. Psychol. 25, 82-9. https://doi.org/10. 1006/ceps.1999.1016 